\title{
EVALUASI PROGRAM PENINGKATAN KOMPETENSI GURU MADRASAH IBDTIDAIYAH DI BALAI DIKLAT KEAGAMAAN MEDAN
}

\author{
Safaruddin $^{1}$, Candra Wijaya ${ }^{2}$, Rahmadi Ali ${ }^{3}$ \\ ${ }^{1,2}$ Universitas Islam Negeri Sumatera Utara \\ ${ }^{3}$ Universitas Muslim Nusantara Al Washliyah \\ 로afaruddinsiahaan@uinsu.ac.id, ${ }^{2}$ candrawijaya@uinsu.ac.id, ${ }^{3}$ rahmadiali@umnaw.ac.id
}

\begin{abstract}
This research was conducted at the Balai Diklat Keagamaan Medan with the aim of evaluating the Madrasah teacher competency improvement program in substantive technical training for the preparation of the RPP for Madrasah Ibtidaiyah Teachers. This type of research is qualitative research using the CIPP (context, input, process and product) evaluation model which focuses on core questions, namely the context of the Madrasah teacher competency improvement program, the input conditions for the Madrasah teacher competency improvement program, the process conditions for the improvement program. Madrasah teacher competencies and product conditions in the Madrasah teacher competency improvement program.
\end{abstract}

The results of this study consisted of 4 components. First. The context dimension is the analysis of the legal basis criteria, that every education and training must have a legal umbrella including Regulation of the Minister of Religion 10 of 2018 concerning amendments to PMA No. 59 of 2015 concerning the Organization and Work Procedure of the Education and Training Center and the Criteria for the Analysis of the Education and Training Organization, that the education and training organization that manages the education and training activities has a legal basis and also has a legal basis at work, the education and training organization is a transition of responsibility from the Kasi to the training committee. Educational and Religious Technical Staff were then given a Letter of Appointment (SK).

Second. The input dimension is the availability of reliable resources such as lecturers / teaching staff, the availability of adequate facilities and infrastructure for training participants, the availability of stateborne funding. Third. The process dimension, namely the implementation of the training program as planned, the widyaswara / teaching staff master the training material presented, the lecturers master the learning method in delivering the material, the lecturers use learning media in presenting the material, the training participants create study groups, practical training participants make RPP. Fourth. Product dimensions. namely teachers do not understand core competencies and basic competencies in lesson plans, teachers can formulate indicators, teachers are able to formulate learning objectives, teachers can determine learning methods, teachers can arrange learning activities, teachers can formulate learning resources and media, teachers can formulate assessments in learning.

Keyword: Program Evaluation, Teacher Competence, Religious Training Center

\begin{abstract}
ABSTRAK
Penelitian ini dilakukan di Balai Diklat Keagamaan Medan dengan tujuan untuk mengevaluasi program peningkatan kompetensi guru Madrasah pada diklat teknis substantif penyusunan RPP Guru Madrasah Ibtidaiyah (MI). Jenis penelitian ini adalah penelitian kualitatif dengan menggunakan model evaluasi CIPP (context, input, process and product) yang difokuskan pada pertanyaan-pertanyaan inti yaitu kondisi konteks program peningkatan kompetensi guru Madrasah, kondisi input pada program peningkatan kompetensi guru Madrasah, kondisi proses pada program peningkatan kompetensi guru Madrasah dan kondisi produk pada program peningkatan kompetensi guru Madrasah.
\end{abstract}


Hasil penelitian ini terdiri dari 4 komponen. Pertama. Dimensi kontek yaitu Analisis kriteria landasan hukum, bahwa setiap diklat harus memiliki payung hukum diantaranya Peraturan Menteri Agama 10 Tahun 2018 tentang perubahan PMA No. 59 Tahun 2015 tentang Organisasi dan Tata Kerja Balai Pendidikan dan Kriteria Analisis Organisasi Diklat, bahwa Organisasi diklat yang mengelola kegiatan diklat memiliki landasan hukum juga memiliki landasan hukum dalam bekerja, organisasi diklat adalah merupakan peralihan tanggungjawab dari Kasi kepada panitia diklat Panitia ini ditetapkan oleh Kasi Diklat Tenaga Teknis Pendidikan dan Keagamaan lalu kemudian diberi SK. Kedua. Dimensi input yaitu tersedianya sumber daya yang handal seperti widyaswara/tenaga pengajar, tersedianya sarana dan prasarana yang memadai bagi peserta diklat, tersedianya pembiayaan yang ditanggung Negara. Ketiga. Dimensi proses, yaitu Pelaksanaan program diklat sesuai dengan yang direncanakan, widyaswara/tenaga pengajar menguasai materi diklat yang disajikan, widyaswara/tenaga pengajar menguasai metode pembelajaran dalam menyampaikan materinya, widyaswara/tenaga pengajar menggunakan media pembelajaran dalam menyajikan materinya, peserta diklat membuat kelompok belajar, peserta diklat praktek membuat RPP. Keempat. Dimensi produk yaitu Guru kurang memahami kompetensi inti dan kompetensi dasar pada RPP, Guru dapat merumuskan indicator, Guru mampu merumuskan tujuan pembelajaran, Guru dapat menentukan metode pembelajaran, Guru dapat menyusun kegiatan pembelajaran, Guru dapat merumuskan sumber dan media pembelajaran, guru dapat merumuskan penilaian dalam pembelajaran.

Kata Kunci: Evaluasi Program, Kompetensi Guru, Balai Diklat Keagamaan

\section{PENDAHULUAN}

Pendidikan adalah sebuah usaha untuk mengarahkan manusia menjadi manusia yang beradab, dengan adanya pendidikan manusia menjadi terarah, terbimbing dan berkarakter. Tanpa pendidikan mausia bisa menjadi primitif atau tidak berperadaban. Pendidikan sendiri berasal dari kata "didik" lalu term ini mendapat awalan "me" sehingga menjadi kata "mendidik", artinya memelihara, melatih, mengarahkan ke arah yang lebih baik. Dalam mengarahkan dan memberi latihan latihan diperlukan adanya ajaran, tuntunan, dan pimpinan mengenai prilaku dan kecerdasan pikiran. Dalam kamus besar bahasa Indonesia (KBBI) pendidikan adalah proses pengubahan sikap dan tata laku seseorang atau kelompok orang dalam usaha mendewasakan manusia melalui upaya pengajaran dan latihan, Departemen Pendidikan Nasional (2000:433). Ada beberapa istilah asing yang biasa dipakai unuk memaknai kata pendidikan dan sudah menjadi istilah penting dalam dunia pendidikan Indonesia diantaranya; padagogie (Yunani) dan education (Education), tarbiyah (Arab). Ketiga istilah ini adalah istilah yang tidak asing lagi didengar dalam dunia pendidikan Indonesia.
Menurut UU RI No. 20 tentang Sistem Pendidikan Nasional tahun 2003: Pendidikan adalah usaha sadar dan terencana untuk mewujudkan suasana belajar dan proses pembelajaran agar peserta didik secara aktif mengembangkan potensi dirinya untuk memiliki kekuatan spiritual, keagamaan, pengendalian diri, kepribadian, kecerdasan, akhlak mulia, serta keterampilan yang diperlukan dirinya, masyarakat, bangsa dan Negara.

Pendidikan adalah suatu proses dalam rangka mempengaruhi peserta didik supaya mampu menyesuaikan diri sebaik mungkin dengan lingkungannya, Oemar Hamalik (1994:3). Dengan demikian pendidikan akan menimbulkan perubahan pada diri peserta didik yang akan memberi dampak kepada kehidupan masyarakat.

Dari beberapa pengertian di atas dapat disimpulkan bahwa pendidikan bermakna upaya sadar yang dilakukan untuk memberikan perubahan kepada peserta didik, baik itu perubahan penampilan, sikap dan tata prilaku. Dengan demikian bahwa pendidikanlah yang dapat memberikan perubahan kepada manusia untuk menjadi manusia yang beradab.

Upaya pendidikan diwujudkan melalui kegiatan yang dilakukan oleh guru dengan energi pembelajaran yang dituangkan dalam muatan materi pembelajaran menjadi proses 
pembelajaran. Proses pembelajaran yang dikehendaki adalah pelayanan unggul terhadap peserta didik untuk mencapai optimalisasi perkembangan mereka. Pelayanan unggul demikian itu dilandaskan pada pendekatan dan konstruk yang tepat, meliputi berbagai komponen yang jelas, sistematik, dinamis, efektif dan efisien, Prayitno (2009:461). Komponen-komponen dalam pendidikan terdiri dari pendidik/guru, siswa, proses pembelajaran, materi pembelajaran, sarana dan prasarana, evaluasi pembelajaran, dan hasil pembelajaran, Umar Tirtarahardja \& La Sulo, S.L (2005:51).

Guru adalah salah satu komponen terpenting dalam dunia pendidikan, keberhasilan lembaga pendidikan terletak pada kualitas seorang guru. Guru adalah bagian terpenting yang berperan dalam memberdayakan peserta didik atau siswa, mengingat guru memiliki peranan dalam proses pelaksanaan pembelajaran, dengan demikian guru memiliki peran besar yang memiliki berkewajiban untuk berperan aktif dalam menempatkan tuntutan masyarakat akan kompetensi yang harus di kuasai oleh peserta didik, dengan memposisikan diri sebagai guru atau tenaga professional dalam arti bahwa guru memiliki tanggung jawab untuk membentuk bakat, minat serta prestasi peserta didik sehingga menguasai suatu kecakapan yang dapat bermanfaat kelak kemudian hari. Dalam UU RI No. 14 Tahun 2005 Tentang Guru dan Dosen, Guru diartikan sebagai tenaga profesional mengandung arti bahwa guru sebagai tenaga pendidik yang secara umum diartikan bahwa profesi guru adalah pekerjaan dalam bidang ilmu pengetahuan dan teknologi dengan cirri dari pekerjaan profesional guru adalah memiliki profesi filosofis dan ketanggapan yang bijak dengan kompetensi yang dimilikinya dalam melaksanakan pekerjaan sehari-hari, dengan ketelitian serta kecermatan dalam menentukan langkah serta sikap pada saat berhadapan dengan peserta didik.

Dalam UU tersebut juga diuraikan tentang hak dan kewajiban guru dan dosen diantaranya adalah:

\section{Hak Guru}

1) memperoleh penghasilan di atas kebutuhan hidup minimum dan jaminan kesejahteraan sosial;

2) Mendapatkan promosi dan penghargaan sesuai dengan tugas dan prestasi kerja;
3) Memperoleh perlindungan dalam melaksanakan tugas dan hak atas kekayaan intelektual;

4) Memperoleh kesempatan untuk meningkatkan kompetensi;

5) Memperoleh dan memanfaatkan sarana dan prasarana pembelajaran untuk menunjang kelancaran tugas keprofesionalan;

6) Memiliki kebebasan dalam memberikan penilaian dan ikut menentukan kelulusan, penghargaan, dan/atau sanksi kepada peserta didik sesuai dengan kaidah pendidikan, kode etik guru, dan peraturan perundangundangan;

7) Memperoleh rasa aman dan jaminan keselamatan dalam melaksanakan tugas;

8) Memiliki kebebasan untuk berserikat dalam organisasi profesi;

9) Memiliki kesempatan untuk berperan dalam penentuan kebijakan pendidikan;

10) Memperoleh kesempatan untuk mengembangkan dan meningkatkan kualifikasi akademik dan kompetensi; dan/atau

11) Memperoleh pelatihan dan pengembangan profesi dalam bidangnya.

\section{Kewajiban Guru}

1) Merencanakan pembelajaran, melaksanakan proses pembelajaran yang bermutu, serta menilai dan mengevaluasi hasil pembelajaran;

2) Meningkatkan dan mengembangkan kualifikasi akademik dan kompetensi secara berkelanjutan sejalan dengan perkembangan ilmu pengetahuan, teknologi, dan seni;

3) Bertindak objektif dan tidak diskriminatif atas dasar pertimbangan jenis kelamin, agama, suku, ras, dan kondisi fisik tertentu, atau latar belakang keluarga, dan status sosial ekonomi peserta didik dalam pembelajaran;

4) Menjunjung tinggi peraturan perundang-undangan, hukum, dan kode etik guru, serta nilai-nilai agama dan etika; dan Memelihara dan memupuk persatuan dan kesatuan bangsa; 
5) Dalam konteks pendidikan Islam guru memiliki keutamaan disebabkan oleh tugas mulia yang diembannya. Tugas yang diemban oleh seorang guru hampir sama dengan tugas seorang Rasul, Asma Hasan Fahmi (1979:165).

Dari pandangan di atas bahwa tugas seorang guru sebagai "warasat al anbiya" yaitu pada hakikatnya mengemban misi rahmatan lil 'alamin, yakni suatu misi yang mengajak manusia untuk tunduk dan patuh pada hukumhukum Allah swt, guna memperoleh keselamatan dunia dan akhirat. Kemudian misi ini dikembangkan kepada pembentukan kepribadian yang berjiwa tauhid, kreatif, beramal saleh dan bermoral tinggi. Untuk melaksanakan tugas sebagai "warasat alanbiya" guru hendaknya bertolak pada amar ma'ruf nahiy munkar" menjadikan prinsip tauhid sebagai pusat kegiatan penyebaran misi iman, Islam dan Ihsan, kekuatan yang dikembangkan oleh guru adalah individualitas, sosial dan moral. Dalam mempersiapkan pembelajaran yang menyenangkan tersebut guru hendaknya memiliki berbagai kompetensi dalam pembelajaran, diantaranya kompetensi kepribadian, kompetensi sosial, kompetensi pedagogik dan kompetensi profesional. Komptensi kepribadian berupa tuntutan seorang guru menjadi model atau panutan (yang harus digugu dan ditiru). Sebagai seorang model guru harus memiliki kompetensi yang berhubungan dengan pengembangan kepribadian diantaranya:

1) Kemampuan yang berhubungan pengamalan ajaran agama sesuai dengan keyakinan ajaran agama yang dianut.

2) Kemampuan untuk menghormati dan menghargai antar umat beragama.

3) Kemampuan untuk prilaku sesuai dengan norma, aturan dan system nilai yang berlaku di masyarakat.

Terkait dengan itu pemerintah sangat mendukung upaya dalam meningkatkan kompetensi guru madrasah, melalui Pusdiklat Kementerian Agama yang diwakilkan kepada Balai Diklat Keagamaan masing-masing daerah, pemerintah berupaya untuk memberikan pendidikan dan pelatihan kepada guru-guru madrasah dalam upaya meningkatkan kompetensi tersebut. Hal ini berarti bahwa peran guru sangat penting sebagai kunci keberhasilan belajar peserta didik. Sebagai upaya untuk meningkatkan kualitas pendidikan dari segi pendidik, maka pemerintah memfasilitasi guru yang ingin meningkatkan kemampuan dalam berbagai bidang yaitu dengan mengadakan DIKLAT (pendidikan dan latihan).

Pendidikan dan Pelatihan (diklat) merupakan dua terminologi yang hampir sama, dari makna maupun pelaksanaannya. Namun ruang lingkup, karakteristik dan tujuan pelaksanaannya berbeda. Pendidikan bermakna suatu proses dalam rangka mempengaruhi peserta didik supaya mampu menyesuaikan diri sebaik mungkin dengan lingkungannya, Oemar Hamalik (1994:3). Dalam Undang-Undang Sistem Pendidikan Nasional Nomor 20 Tahun 2003, dikemukakan bahwa "pendidikan adalah usaha sadar dan terencana untuk mewujudkan suasana belajar dan proses pembelajaran agar peserta didik secara aktif mengembangkan potensi dirinya untuk memiliki kekuatan spiritual keagamaan, pengendalian diri, kepribadian, kecerdasan, akhlak mulia, serta ketrampilan yang diperlukan dirinya, masyarakat, bangsa dan negara.

Pada dasarnya pendidikan dan pelatihan mempunyai sasaran pengembangan sumber daya manusia terhadap tugas pekerjaan yang sementara digeluti dan untuk menghadapi tantangan-tantangan yang bakal terjadi pada tuntutan perubahan dan perkembangan dimasa yang akan datang.

Sedangkan tujuan diadakannya diklat adalah untuk memberikan kesempatan kepada personil dalam meningkatkan kecakapan dan keterampilan mereka, terutama dalam bidangbidang yang berhubungan dengan kepemimpinan atau manajerial yang diperlukan dalam pencapaian tujuan organisasi. UU No. 43 Tahun 1999 tentang Pokok-pokok Kepegawaian, pada pasal 31 mengatur tentang Pendidikan/Pelatihan (Diklat) pegawai yaitu untuk mencapai daya guna dan hasil guna yang sebesar- besarnya, diadakan pengaturan dan penyelenggaraan Pendidikan dan Pelatihan (Diklat) jabatan Pegawai.

Berdasarkan fokus penelitian di atas, maka pertanyaan yang akan dicari jawabannya melalui sebuah penelitian disertasi ini sebagai berikut:

1) Bagaimana evaluasi terhadap konteks program peningkatan kompetensi guru madrasah pada Diklat Teknis Subtantif Penyusunan RPP Guru Madrasah Ibtidaiyah (MI) di Balai Diklat Medan? 
2) Bagaimana evaluasi terhadap masukkan (input) program peningkatan kompetensi guru Kelas madrasah pada Diklat Teknis Subtantif Penyusunan RPP Guru Madrasah Ibtidaiyah (MI) di Balai Diklat Medan?

3) Bagaimana evaluasi terhadap proses program peningkatan kompetensi guru madrasah pada Diklat Teknis Subtantif Penyusunan RPP Guru Madrasah Ibtidaiyah (MI) di Balai Diklat Medan?

4) Bagaimana evaluasi terhadap produk program peningkatan kompetensi guru madrasah pada Diklat Teknis Subtantif Penyusunan RPP Guru Madrasah Ibtidaiyah (MI) di Balai Diklat Medan?

\section{TINJAUAN PUSTAKA}

\subsection{Pengertian Evaluasi Program}

Evaluasi secara bahasa berasal dari bahasa Inggris yaitu Evaluation yang memiliki arti penilaian atau penaksiran. Sedangkan menurut beberapa ahli seperti Oemar Hamalik, evaluasi adalah. "suatu proses atau kegiatan yang sistematis dan menentukan kualiatas (nilai atau arti) daripada sesuatu berdasarkan pertimbangan dan kriteria tertentu, Oemar Hamalik (2008:180). Sedangkan menurut Wina Sanjaya evaluasi adalah. "suatu proses yang sangat penting dalam pendidikan guru, tetapi pihak-pihak yang terkait dalam program itu seringkali melalaikan atau tidak menghayati sungguh-sungguh proses evaluasi tersebut, Wina Sanjaya (2006:187-194). Sedangkan menurut Zainal Abidin evaluasi adalah "proses untuk melihat apakah perencanaan yang sedang di bangun berhasil sesuai dengan harapan awal atau tidak, Zainal Abidin (2010:3).

Anderson memandang evaluasi sebagai sebuah proses menentukan hasil yang telah dicapai beberapa kegiatan yang direncanakan untuk mendukung tercapainya tujuan. Beliau juga mengemukakan bahwa evaluasi adalah kegiatan mencari sesuatu yang berharga tentang sesuatu; dalam mencari sesuatu tersebut, juga mencari informasi yang bermanfaat dalam menilai keberadaan suatu program, produksi, prosedur serta alternatif strategi yang diajukan untuk mencapai tujuan yang sudah ditentukan, Scarvia Anderson (1975:58).

Berdasarkan pengertian dari beberapa ahli di atas evaluasi adalah kegiatan terencana dan sistematis untuk mengukur suatu objek kegiatan berdasarkan pertimbangan yang matang berdasarkan prosedur. Jadi dapat dipahami bahwa evaluasi merupakan kegiatan yang sangat penting dalam proses pembelajaran. Evaluasi program termasuk pengukuran kinerja program, sumber biaya, aktivitas program, outcomes program, dan pengujian asumsi sementara yang berhubungan dengan tiga elemen ini.

\subsection{Prinsip Evaluasi Program}

Dalam mendesain dan melakukan proses atau kegiatan evaluasi seorang guru hendaknya mempertimbangkan prinsip-prinsip berikut, Oemar Hamalik (2008:180).

1) Prinsip berkesinambungan (continuity): Maksud Prinsip ini adalah kegiatan evaluasi dilaksanakan secara terus-menerus. Evaluasi tidak hanya dilakukan sekali setahun atau sekalu setiap semester, melainkan evaluasi juga dilakukan secara berkelanjutan mulai dari proses pembelajaran sampai siswa tersebut menampatkan studinya di lembaga tersebut.

2) Prinsip menyeluruh (comprehensive): Prinsip ini maksudnya adalah dalam melakukan evaluasi haruslah melihat keseluruhan dari aspek kognitif, apektif, dan psikomotorik.

3) Prinsip objektivitas (objektivity): maksudnya adalah menilai proses pembelajaran dan siswa secara objektif berdasarkan keadaan yang sesungguhnya, bukan dipengaruhi oleh faktor-faktor lain.

4) Prinsip valididitas (validity): artinya evaluasi yang dilakukan harus menggunakan alat ukur yang shahih. yaitu alat ukur yang telah teruji dapat mengukur objek dengan sebenarbenarnya.

Prinsip ini memberikan arahan dalam mengevaluasi sebuah program atau kegiatan, keempat prinsip ini harus dilakukan secara optimal, prinsip-prinsip ini dilakukan bukan hanya sekedar untuk memenuhi standar tetapi lebih kepada untuk peningkatan sebuah program.

\subsection{Evaluasi Program Model CIPP}

Evaluasi program model CIPP merupakan model yang paling banyak dikenal dan diterapkan oleh para evaluator. Oleh karna itu, uraian yang diberikan lebih panjang dibanding dengan model-model lainnya, Suharsimi Arikunto (2009:45). Model ini bertitik tolak pada pandangan bahwa keberhasilan progran pendidikan dipengaruhi oleh berbagai faktor, seperti: karakteristik 
peserta didik dan lingkungan, tujuan program dan peralatan yang digunakan, prosedur dan mekanisme pelaksanaan program itu sendiri. Evaluasi model ini bermaksud membandingkan kinerja dari berbagai dimensi program dengan sejumlah kriteria tertentu, untuk akhirnya sampai pada deskripsi dan judgment mengenai kekuatan dan kelemahan program yang dievaluasi. CIPP yang merupakan sebuah singkatan dari huruf awal empat buah kata, yaitu:

\section{Context Evaluation : Evaluasi terhadap konteks \\ Input Evaluation $\quad$ Evaluasi terhadap masukkan \\ Process Evaluation : Evaluasi terhadap proses \\ Product Evaluation : Evaluasi terhadap hasil}

Keempat kata yang disebutkan dalam singkatan CIPP merupakan sasaran evaluasi yang tidak lain adalah komponen dari proses sebuah program kegiatan. Dengan kata lain CIPP adalah model evaluasi yang memandang program yang dievaluasi sebagai sebuah system. Dengan demikian, jika tim evaluator sudah menentukan model CIPP sebagai model yang akan digunakan untuk mengevaluasi program yang ditugaskan maka mau tidak mau mereka harus menganalisis program tersebut berdasarkan komponen-komponennya.

Inti evaluasi adalah untuk mengambil keputusan tentang kurikulum dalam arti luas. Evaluasi sebagai "...proses menggambarkan, mendapatkan, dan mengembangkan informasi yang berguna bagi penetapan alternatifalternatif keputusan". Para pakar evaluasi membagi tiga tipe keputusan yang dapat diambil sebagai tindak lanjut evaluasi. Keputusan tersebut adalah: (1) keputusankeputusan yang terkait dengan pengembangan pembelajaran, (2) keputusan-keputusan yang terkait dengan para individu seperti guru dan siswa, serta (3) keputusan-keputusan yang terkait dengan peraturan administrative sekolah. misalnya bagaimana sistem sekolah yang baik, serta bagaimana peraturan-peraturan tentang warga sekolah, Farida Yusuf Tayib Napis (2008:3).

Dalam evaluasi model CIPP, dievaluasi pengaruh keputusan-keputusan manajemen yang terkait dengan kurikulum. Proses utama pengevaluasian ada tiga, yaitu: (1) pengungkapan informasi yang dibutuhkan, (2) pengumpulan data, dan (3) pengembangan informasi terhadap hal-hal penting. Berdasarkan pengevaluasian, ada empat jenis keputusan yang dapat dirumuskan yaitu: (1) keputusan tentang perencanaan, (2) keputusan tentang penstrukturan, (3) keputusan tentang pengimplementasian, dan (4) keputusan tentang proses pengulangan. Sesuai dengan jenis keputusan yang diambil, diklasifikasikan empat tipe pengevaluasian. Tipe-tipe tersebut adalah: (1) konteks, (2) masukan, (3) proses, dan (4) produk. Evaluasi tentang konteks dimaksudkan untuk memperoleh gambaran yang cermat tentang lingkungan pembelajaran siswa.

\section{METODE}

Jenis penelitian ini adalah penelitian kualitatif yaitu penelitian yang bersifat deskriptif. Jadi prosedur penelitian ini, akan menghasilkan data deskriptif, berupa kata-kata tertulis atau lisan dari orang-orang dan perilaku yang dapat diamati. Penelitian deskriptif kualitatif ini bertujuan untuk mendeteksikan suatu keadaan atau fenomena-fenomena secara apa adanya, Nana Syaodih Sukmadinata (2007:18).

Model evaluasi yang peneliti pilih adalah evaluasi model CIPP (contex, input, proses, product). Alasan peneliti menggunakan evaluasi model CIPP dikarenakan model ini lebih konprehensip dibandingkan dengan model evaluasi yang ada. Selain itu evaluasi model CIPP akan diakhiri dengan rekomendasi dari peneliti, diantaranya adalah:

1) Program peningkatan kompetensi guru madrasah di Balai Diklat Medan berhasil dan dapat diteruskan

2) Program peningkatan kompetensi guru madrasah di Balai Diklat Medan diteruskan dengan adanya perbaikanperbaikan

3) Program peningkatan kompetensi guru madrasah di Balai Diklat Medan dihentikan, Sukardi (2015:62).

Kemudian selain memberikan rekomendasi-rekomendasi terhadap Program peningkatan kompetensi guru madrasah di Balai Diklat Medan, evaluasi CIPP juga akan mengungkapkan kekuatan-kekuatan program serta persoalan-persoalan yang krusial pada setiap penyelenggaraan program. Program yang dievaluasi pada penelitian ini hanya difokuskan pada Diklat Teknis Substantif Penyusunan RPP Guru Kelas Madrasah Ibtidaiyah (MI) Kementerian Agama Provinsi Sumatera Utara Tahun 2020 


\section{HASIL PEMBAHASAN}

\subsection{Hasil}

Keberadaan Balai Diklat Keagamaan Medan telah menempuh sejarah yang panjang, sejak mulai berdiri sampai pada saat ini. Kehadiran BDK pada periode awal didasarkan pada Keputusan Menteri Agama Nomor. 1185/KI tanggal 20 Februari 1946, walaupun tidak secara eksplisit menyebutnya dengan organisasi pendidikan dan latihan pegawai. Kemunculannya tidak terlalu lama dengan awal lahirnya Kementerian Agama pada tanggal 3 januari 1946 yang diumumkan oleh Pemerintah Negara RI di Yogyakarta. Pada mulanya susunan organisasi Kementerian Agama yang dibentuk berdasarkan Keputusan Menteri Agama Nomor. 1185/KI tanggal 20 Februari 1946 terdiri dari delapan bagian, yaitu:

$\begin{array}{lll}\text { 1. } & \text { Bagian A } & \text { : Sekretariat } \\ \text { 2. } & \text { Bagian B } & \text { : Kepenghuluan } \\ \text { 3. } & \text { Bagian C } & \text { : Pendidikan Agama } \\ \text { 4. } & \text { Bagian D } & \text { : Penerangan Agama } \\ \text { 5. } & \text { Bagian E I } & \text { : Masehi Kristen } \\ \text { 6. } & \text { Bagian E III } & \text { : Masehi Katholik } \\ \text { 7. } & \text { Bagian F } & \text { : Pegawai } \\ \text { 8. } & \text { Bagian G } & \text { : Keuangan }\end{array}$

Susunan organisasi Balai Pendidikan dan Latihan Pegawai teknis Keagamaan adalah sebagai berikut:

1) Sub bagian tata usaha, mempunyai tugas melaksanakan tata usaha dan rumah tangga termasuk perpustakaan, asrama dan laboratorium serta tugastugas lainnya yang bersifat pelayanan terhadap pelaksanaan pendidikan dan pelatihan.

2) Seksi Pendidikan dan Latihan Guru Agama; melaksanakan kegiatan pendidikan dan latihan bagi guruguru agama.

3) Seksi Pendidikan dan Latihan Tenaga Teknis Keagamaan, melaksanakan pendidikan dan latihan bagi pegawai dan tenaga teknis keagamaan lainnya.

4) Staff Pengajar

Dalam kaitan ini ada perubahan dalam susunan Organisasi Balai Pendidikan dan Pelatihan Keagamaan (Balai Diklat Keagamaan) sesuai dengan KMA Nomor 345 tahun 2004 adalah:

1) Sub Bagian Tata Usaha; melaksanakan tugas pelayanan dan administrasi bagi satuan kerja di lingkungan Balai Diklat Keagamaan;
2) Seksi Diklat Tenaga Administrasi; mempunyai tugas melakukan penyiapan dan pelaksanaan program, kegiatan akademik, kepesertaan dan sarana diklat struktural, diklat Kepemimpinan, fungsional dan teknis administrasi.

3) Seksi Diklat Tenaga Teknis Keagamaan; mempunyai tugas melakukan penyiapan dan pelaksanaan program, kegiatan akademik, kepesertaan dan sarana diklat fungsional dan teknis keagamaan.

4) Kelompok Jabatan Fungsional; mempunyai tugas melakukan kegiatan sesuai bidang keahliannya. Termasuk kedalam kelompok jabatan fungsional ini adalah widyaswara dan pustakawan.

\subsection{Pembahasan}

1) Aspek konteks program peningkatan kompetensi guru madrasah pada Diklat Teknis Subtantif Penyusunan RPP Guru Kelas Madrasah Ibtidaiyah (MI) di Balai Diklat Medan.

Pada aspek ini ada dua komponen yang menjadi inti dari penelitian ini yaitu Pertama. Adanya landasan hukum dalam setiap kegiatan diklat yang diselenggarakan Balai Diklat Keagamaan yang ada di seluruh Indonesia. Dalam pelaksanaan Pendidikan dan Latihan (diklat) yang diselenggarakan oleh BDK Medan terlebih dahulu harus disiapkan payung hukumnya agar dalam pelaksanaannya terkesan tidak asal jadi dan tujuan yang dicapai sesuai dengan UU yang berlaku di negera kita. Landasan hukum tersebut berupa, 1) Undangundang RI Nomor 5 tahun 2014 tentang Aparatur Sipil Negara (ASN), 2) Peraturan Pemerintah RI Nomor 11 Tahun 2017 tentang Manajemen Pegawai Negeri Sipil, 3) Peraturan Menteri Agama RI Nomor 42 Tahun 2016 tentang Organisasi dan Tata Kerja Kementerian Agama, 4) Peraturan Menteri Agama 10 Tahun 2018 tentang perubahan PMA No. 59 Tahun 2015 tentang Organisasi dan Tata Kerja Balai Pendidikan dan Pelatihan Keagamaan, 5) Keputusan Menteri Agama RI Nomor 75 Tahun 2015 tentang Penyelenggaraan Pendidikan dan Pelatihan Pegawai pada Kementerian Agama, 6) Keputusan Kepala Badan Litbang dan Diklat Kementerian Agama Nomor 62 Tahun 2017 tentang Kurikulum Pendidikan dan Pelatihan Tenaga Teknis Pendidikan dan Keagamaan, 7) 
Keputusan Menteri Agama Nomor 148 Tahun 2014 Tentang Penetapan Honorarium bagi Penyuluh Agama non PNS, 8) DIPA Balai Diklat Keagamaan Medan Tahun 2020 Nomor. 025.11.425350/2020 tanggal 05 Januari 2020. Kedua. Adanya organisasi diklat. Organisasi diklat yang ada di BDK Medan memiliki indikator kerja, yaitu menentukan tujuan dan sasaran diklat, menentukan kurikulum diklat, menentukan peserta diklat, menetapkan widyaswara/tenaga pengajar, dan melaksanakan evaluasi terhadap semua komponen diklat (panitia, peserta dan widyaswara).

2) Aspek input program peningkatan kompetensi guru madrasah pada Diklat Teknis Subtantif Penyusunan RPP Guru Kelas Madrasah Ibtidaiyah (MI) di Balai Diklat Medan

Pada aspek ini ada tiga komponen utama yang menjadi inti dari penelitian ini, diantaranya adalah Pertama. Kriteria sumber daya manusia (SDM). Pada kriteria SDM ini ada dua focus pembahasan yaitu penetapan widyaswara dan syarat menjadi widyaswara. Tenaga pengajar /Widyaswara yang mengajar pada program Diklat Teknis Substantif Penyusunan RPP Guru MI Kementerian Agama Tahun 2020 adalah orang-orang yang profesional. Sebagaimana yang telah dijelaskan dalam kajian teori bahwa salah satu indikator profesional dari seorang guru adalah penguasaan terhadap materi pembelajaran.

Terkait dengan syarat-syarat untuk menjadi narasumber/widyaswara yaitu Pertama, harus ASN, artinya orang-orang yang akan menjadi pemateri di BDK Medan ini harus berstatus Pegawai Negeri Sipil minimal memiliki pangkat/golongan Penata-III/c. Kedua, Memiliki gelar minimal Magister, karena yang akan dihadapi oleh widyaswara/narasumber adalah guru yang memiliki gelar minimal S1, jadi widyaswara harus bergelar Magister. Ketiga, memiliki jabatan di unit kerja masing-masing. Keempat, memiliki pengalaman pada mata diklat yang akan diampu. Kelima, jika dosen maka ia ahli dalam bidang tertentu. Keenam. Jika guru maka ia harus punya jabatan sebagai kepala sekolah, sudah sesuai dengan prosedur yang telah ditetapkan dan tertuang di dalam Peraturan Kementerian Pendayagunaan Aparatur Negara dan Reformasi Birokrasi RI Nomor 22 Tahun 2014.
Kedua. Kriteria sarana dan prasarana. Terkait dengan ini bahwa:

a) Ruang kelas diklat telah memenuhi standar diklat yang telah ditetapkan oleh Balitbang Kementerian Agama. Bahwa BDK Medan sudah memiliki 4 unit ruang kelas diklat, masing-masing ruang kelas berukuran lebih kurang 15 x $20 \mathrm{~m}$ dan masing-masing kelas mampu menampung maksimal 50 orang. Masing-masing ruang kelas sudah dilengkapi dengan perangkat audio-visual dan pendingin ruangan, dan di dalam ruangan sudah tersedia meja dan kursi peserta.

b) Asrama peserta diklat yang disediakan untuk peserta juga sudah memadai. Setiap kamar sudah tersedia tempat tidur dan bantalnya.dan juga sudah disediakan pendingin ruangan. Melihat dari ruangan asrama tersebut nampaknya inilah yang membuat betah para peserta diklat.

c) Ruang makan peserta diklat juga sudah memadai. Posisi ruang makan tidak jauh dari ruang kelas diklat. Setiap peserta akan mendapatkan kesempatan ke ruangan makan pada saat, istirahat yaitu pada pukul 10.00, pukul 12.00 dan pukul 15.00 wib. Ruang makan ini juga memberi kenyamanan kepada peserta diklat, karena sudah disusun rapi. Kemudian ditambah lagi dengan menu yang memang berkualitas.

3) Aspek proses program peningkatan kompetensi guru madrasah pada Diklat Teknis Subtantif Penyusunan RPP Guru Kelas Madrasah Ibtidaiyah (MI) di Balai Diklat Keagamaan Medan.

Yang menjadi komponen penting dalam penelitian ini adalah kriteria pelaksanaan program peningkatan kompetensi guru madrasah pada Diklat Teknis Substantif Penyusunan RPP Guru Kelas MI di Balai Diklat Keagamaan Medan yaitu:

(1) Pelaksanaan Program diklat sesuai dengan yang direncanakan.

Pada permasalahan ini peneliti memberikan nilai baik, karena peneliti menilai bahwa pelaksanaan program diklat ini sesuai dengan yang direncanakan. Hal ini bukan tidak memiliki alasan, karena berdasarkan hasil wawancara bahwa tidak satu pun peserta mengeluhkan tentang schedule atau jadwa pelatihan. Kemudian berdasarkan observasi, bahwa peneliti menyaksikan setiap peserta sudah mulai berdatangan satu hari pelaksanaan 
diklat, kemudian setelah peserta diklat berdatangan mereka langsung registrasi di ruang pendaftaran lalu kemudian panitia penyelenggara mengarahkan peserta diklat untuk memasuki asrama. Kemudian berdasarkan studi dokumentasi bahwa peneliti melihat dari mulai surat pemberitahuan (undangan kepada peserta) yang disampaikan melalui email masing-masing unit kerja di Kementerian Agama Sumatera Utara berjalan sesuai rencana.

$$
\begin{aligned}
& \text { Widyaswara/narasumber menguasai } \\
& \text { materi diklat }
\end{aligned}
$$

Pada aspek ini peneliti memberikan nilai baik. Pemberian nilai ini bukan tanpa alasan. Pertama berdasarkan wawancara dengan peserta diklat bahwa mereka merasa puas dengan widyaswara/ tenaga pengajar dengan materinya. Para widyaswara/ tenaga pengajar begitu sangat menguasai materi saat berada di ruang kelas. Hal ini menandakan bahwa pemilihan dan penetapan widyaswara/ tenaga pengajar oleh BDK sudah sangat tepat lebih mengutamakan aspek profesionalisme. Kedua berdasarkan observasi, peneliti melihat bahwa sepertinya tidak ada widyaswara/ tenaga pengajar yang amatiran, hal ini terlihat jelas ketika widyaswara/ tenaga pengajar sedang berada di ruang kelas, mereka sangat menguasai materi bahkan ada sebagian widyaswara/ tenaga pengajar yang menguasai UU di luar kepala.

Widyaswara/ tenaga pengajar menguasai metode pembelajaran

Pada aspek ini peneliti hanya memberi nilai cukup. Peneliti melihat bahwa metode yang digunakan oleh widyaswara/ tenaga pengajar hanya metode klasik dalam menyampaikan materinya yaitu metode ceramah dan metode penugasan. Peneliti belum menemukan metode baru yang digunakan oleh widyaswara/ tenaga pengajar dalam menyampaikan materi. Jadi matode ini adalah metode yang biasa digunakan oleh guru-guru. Kemudian berdasarkan dari hasil wawancara kepada peserta bahwa widyaswara/ tenaga pengajar selalu menggunakan metode ceramah. (4) Widyaswara/ tenaga pengajar menggunakan media pembelajaran.

Pada aspek ini peneliti memberikan nilai baik. Hal ini didasari oleh dua hal pertama berdasarkan wawancara kepada peserta bahwa media yang digunakan oleh widyaswara/ tenaga pengajar cukup memuaskan mulai dari infokus, modul dan media lainnya yang disesuaikan dengan materi masing-masing. Begitu juga dengan observasi peneliti bahwa widyaswara/ tenaga pengajar banyak menggunakan media pembelajaran dalam menyampaikan matarinya, media itu berupa infokus, modul dan juga media yang disesuaikan dengan materi.

(5) Peserta Diklat Membuat Kelompok Belajar

Pada aspek ini peneliti memberikan nilai baik. Hal ini dikarenakan bahwa peserta diklat sangat antusias jika di instruksikan oleh widyaswara/ tenaga pengajar untuk membuat kelompok belajar, maka dengan segera para peserta diklat langsung membuat kelompok belajar. Dari hasil observasi peneliti bahwa setiap widyaswara/ tenaga pengajar selalu menerapkan metode ini pada saat materi praktikum. Karena memang peserta diklat dituntut untuk mempraktikkan segala bentuk materi yang disampaikan oleh widyaswara/ tenaga pengajar.

(6) Peserta diklat praktek membuat RPP

Pada aspek ini peneliti memberikan nilai baik. Berdasarkan hasil wawancara bahwa setiap peserta diklat dilatih dan disuruh menyusun RPP. Peserta diklat diberikan pemahaman tentang aspek-aspek yang ada pada RPP, lalu kemudian dibimbing tentang tata cara merumuskan tujuan, kompetensi dasar, kompetensi inti dan aspek-aspek lain yang ada di RPP. Setelah teori itu semua diberikan kepada peserta lalu kemudian peserta mempraktekkan menyusun RPP pada satu mata pelajaran.

4) Aspek produk program peningkatan kompetensi guru madrasah pada Diklat Teknis Subtantif Penyusunan RPP Guru Kelas Madrasah Ibtidaiyah (MI) di Balai Diklat Keagamaan Medan.

Pada aspek ini ada 7 komponen penting dalam penelitian ini yaitu

(1) Guru dapat memahami kompetensi inti dan kompetensi dasar.

Pada poin ini peneliti memberi nilai kurang dikarenakan dari hasil wawancara dengan guruguru alumni diklat penyusunan RPP, guru hanya mengetahui sebatas $\mathrm{KI}$ dan KD merupakan ketetapan dari pemerintah, namun ketika ditanya tentang makna dan penjelasannya guru tidak bisa menjelaskan secara detail. Bahkan dari pejelasan tersebut guru terkesan asal dalam menjawab pertanyaan dari peneliti. Atas dasar ini peneliti 
menyimpulkan bahwa guru-guru tidak memahami apa sebenarnya yang dimaksud dengan Kompetensi Inti dan Kompetensi Dasar.

(2) Guru dapat merumuskan indicator.

Pada poin ini peneliti memberi nilai baik, hal ini dikarenakan guru-guru sudah mampu merumuskan indicator perbidang studi. Berdasarkan hasil wawancara di atas menunjukkan bahwa guru sudah tau penempatan kata untuk indikator dalam setiap bidang studi. Indikator dirumuskan dengan menggunakan kata kerja operasional yang dapat diukur. Kemudian berdasarkan studi dokumentasi RPP, bahwa telah ditemukan kata kerja operasional dalam indikator pembelajaran.

(3) Guru dapat merumuskan tujuan pembelajaran.

Pada komponen ini peneliti memberi nilai baik, hal ini dikarenakan beberapa guru yang peneliti wawancarai mengerti bagaimana cara merumuskan tujuan pembelajaran, karena memang tujuan pembelajaran sangat ditekankan kepada student center yaitu berbasis kepada peserta didik. Kemudian berdasarkan studi dokumen RPP, peneliti melihat bahwa guru sudah bisa merumuskan tujuan pembelajaran dengan baik. Kemudian di RPP tersebut peneliti melihat bahwa tujuan pembelajaran yang dibuat sudah disesuaikan dengan tujuan instruksional yang telah ditetapkan pemerintah.

(4) Guru dapat menentukan metode pembelajaran.

Pada komponen ini memberikan nilai baik, karena dalam wawancara peneliti dengan guru bahwa guru tersebut sudah paham betul metode apa yang akan digunakan dalam pembelajaran. Metode-metode tersebut penggunaannya berbeda-beda sesuai dengan kebutuhan pembelajaran per bidang studi. Kemudian dalam dokumen RPP yang peneliti lihat, bahwa tercatat ada beberapa metode yang sudah ditentukan dalam pembelajaran diantaranya adalah metode ceramah, metode demonstrasi, metode penugasan, metode praktek dan beberapa metode lainnya.

(5) Guru dapat menyusun kegiatan pembelajaran.

Pada komponen ini peneliti memberi nilai baik, hal ini dikarenakan guru -guru sudah mampu untuk menyusun kegiatan pembelajaran. Di kegiatan pembelajaran inilah pokok dari isi RPP. Di kegiatan pembelajaran ini lah pembelajaran di kemas. Kemudian di kegiatan pembelajaran ini akan ditentukan bagaimana kegiatan pendahuluan, inti dan penutupan. Di kegiatan inti tertulis siklus eksplorasi yang bermakna guru melibatkan peserta didik dalam mencari dan menghimpun informasi, menggunakan media untuk memperkaya pengalaman mengelola informasi, memfasilitasi peserta didik berinteraksi sehingga peserta didik aktif. Kemudian siklus elaborasi yaitu guru mendorong peserta didik untuk menulis hasil yang diperoleh melalui kegiatan eksplorasi, mendiskusikan, mendengar pendapat untuk lebih mendalami sesuatu. Menganalisis kekuatan atau kelemahan argumen, mendalami pengetahuan tentang sesuatu, membangun kesepakatan melalui kegiatan kooperatif dan kolaborasi. Kemudian siklus konfirmasi yaitu guru memberikan umpan balik terhadap apa yang dihasilkan atau dikerjakan oleh peserta didik melalui pengalaman belajar, kemudian guru memberikan apresiasi kepada peserta didik terhadap hasil kerja mereka.

(6) Guru dapat menentukan sumber dan media pembelajaran.

Pada komponen ini peneliti memberi nilai baik, hal ini dikarenakan berdasarkan hasil wawancara dengan guru-guru, pertama mereka sudah bisa membedakan antara sumber belajar dan media belajar. kedua, mereka sudah bisa memilih mana yang sumber belajar dan mana yang media belajar. Dalam dokumen RPP yang peneliti lihat bahwa sumber belajar yang mereka pilih berupa buku, narasumber. Sedangkan media belajar yang mereka pilih adalah leptop, proyektor, dan media lainnya. Maka berdasarkan hal inilah peneliti memberikan nilai baik.

(7) Guru dapat melakukan penilaian.

Pada komponen ini peneliti juga memberikan nilai baik. Hal ini dikarenakan dalam wawancara dengan guru bahwa mereka sudah bisa menentukan prosedur penilaian dan instrument penilaian. Prosedur penilaian terdiri atas penilaian proses dan penilaian hasil belajar. Sedangkan instrument penilaian terdiri dari penilaian proses dan penilaian hasil belajar. Pada presedur penilaian, penilaian dilakukan dilakukan pada saat jam pembelajaran di mulai sampai akhir pembelajaran, dan penilaian hasil belajarnya menggunakan tes berbentuk lisan dan tulisan. Sedangkan instrument penilaian dilakukan dengan menggunakan penilaian kinerja dan penilaian produk, penilaian hasil 
belajarnya menggunakan tes pilihan berganda, isian dan essay.

\section{KESIMPULAN}

Dari hasil penelitian dan hasil analisis data yang peneliti lakukan, maka pada kesimpulan ini peneliti akan menyampaikan bahwa program peningkatan kompetensi guru madrasah pada diklat teknis subtantif penyusunan RPP di Balai Diklat Keagamaan Medan ditinjau dari empat dimensi yaitu konteks, input, proses dan produk, berikut penjelasan dari masing-masing dimensi:

1. Konteks program peningkatan kompetensi guru madrasah pada diklat teknis substantif penyusunan RPP di Balai Diklat Keagamaan Medan, baik dari Analisis kriteria landasan hukum dan Kriteria Analisis Organisasi Diklat, disimpulkan bahwa: (a) program peningkatan kompetensi guru madrasah pada diklat teknis subtantif penyusunan RPP sudah memiliki payung hukum diantaranya Peraturan Menteri Agama 10 Tahun 2018 tentang perubahan PMA No. 59 Tahun 2015 tentang Organisasi dan Tata Kerja Balai Pendidikan dan Pelatihan Keagamaan, dan Keputusan Menteri Agama RI Nomor 75 Tahun 2015 tentang Penyelenggaraan Pendidikan dan Pelatihan Pegawai pada Kementerian Agama, dan Keputusan Kepala Badan Litbang dan Diklat Kementerian Agama Nomor 62 Tahun 2017 tentang Kurikulum Pendidikan dan Pelatihan Tenaga Teknis Pendidikan dan Keagamaan, (b) Organisasi diklat yang mengelola kegiatan diklat memiliki landasan hukum juga memiliki landasan hukum dalam bekerja, organisasi diklat adalah merupakan peralihan tanggungjawab dari Kasi kepada panitia diklat Panitia ini ditetapkan oleh Kasi Diklat Tenaga Teknis Pendidikan dan Keagamaan lalu kemudian diberi SK. Setiap angkatan Diklat maka panitia berganti. Panitia tersebut bertugas mengatur segala keperluan selama diklat berlangsung hingga menyusun laporan akhir penyelenggaraan. Dengan demikian dapat direkomendasikan bahwa dari aspek konteks program diklat teknis substantif penyusunan RPP di Balai Diklat Keagamaan Medan tahun 2020 dapat diteruskan.

2. Input program peningkatan kompetensi guru madrasah pada diklat teknis substantif penyusunan RPP di Balai Diklat Keagamaan Medan dapat disimpulkan bahwa: (a) Sumber Daya Manusia adalah widyaswara/tenaga pengajar yang diberi amanat untuk memberikan pengajaran di Balai Diklat hal ini sesuai dengan Peraturan Menteri Pendayagunaan Aparatur Negara No. 14 Tahun 2009 Bab 1 Pasal 1 ayat 2 tentang ketentuan umum: "Widyaiswara adalah jabatan fungsional yang mempunyai ruang lingkup, tugas, tanggung jawab, dan wewenang untuk mendidik, mengajar dan/atau melatih pegawai negeri sipil pada Lembaga Diklat Pemerintah". Dengan demikian tugas dari widyaiswara itu sendiri adalah mendidik, mengajar, dan atau melatih Pegawai Negeri Sipil pada Lembaga Diklat Pemerintah. Secara lebih rinci tugas dan tanggung jawab widyaiswara adalah menyusun analisis kebutuhan Diklat, menyusun kurikulum, menyusun bahan pembelajarn, menyusun tes hasil belajar Diklat yang diselenggarakan, melaksanakan Diklat, dan melaksanakan evaluasi program Diklat. Peran utama widyaiswara dalam penyelenggaran Diklat adalah mengaktualisaikan rancangan Diklat menjadi kegiatan pengelolaan pembelajaran, kemudian syarat menjadi widyaswara/tenaga pengajar selain yang sudah ditetapkan pada Peraturan Kementerian Pendayagunaan Aparatur Negara dan Reformasi Birokrasi RI Nomor 22 Tahun 2014 juga BDK memiliki syarat tersendiri yaitu minimal bergelar Magister, hal ini bukan tanpa sebab, karena peserta diklat yang dibina rata-rata minimal sarjana (S1), (b) sarana dan prasarana yang terdiri dari ruang kelas diklat, asrama peserta dan ruang makan cukup memadai dan masuk dalam kategori baik, sehingga layak untuk selanjutnya digunakan pada diklat-diklat yang lain, (c) dana atau anggaran pada diklat teknis substantif semuanya berasal dari anggaran Daftar Isian Pelaksana Anggaran (DIPA) tahun 2020, artinya setiap peserta tidak dibebankan untuk membayar selama acara diklat justru setiap peserta akan diberikan pengganti uang transport berdasarkan domisilinya. Dengan demikian dapat direkomendasikan bahwa aspek input program diklat teknis substantif penyusunan RPP di Balai Diklat 
Keagamaan Medan tahun 2020 dapat diteruskan.

3. Proses program peningkatan kompetensi guru madrasah pada diklat teknis substantif penyusunan RPP di Balai Diklat Keagamaan Medan dapat disimpulkan bahwa: (a) Pelaksanaan program diklat sesuai dengan yang direncanakan, mulai dari surat pemanggilan peserta diklat di masing-masing wilayah kerja sampai kepada pelaksanaan diklat yang semuanya berjalan dengan baik dan sesuai rencana, (b) widyaswara/tenaga pengajar menguasai materi diklat yang disajikan, dalam menyampaikan materinya widyaswara/tenaga pengajar begitu sangat menguasai materinya sehingga para peserta diklat sangat antusias dalam mengikuti kegiatan materi, (c) widyaswara/tenaga pengajar menguasai metode pembelajaran dalam menyampaikan materinya, banyak metode-metode yang digunakan dalam menyampaikan materi, seperti metode ceramah, diskusi, penugasan, kelompok dan metode yang disesuaikan dengan materinya masing-masing, (d) widyaswara/tenaga pengajar menggunakan media pembelajaran dalam menyajikan materinya. Media yang digunakan oleh widyaswara/tenaga pengajar beragam mulai dari infokus, leptop, papan tulis dan modul, (e) peserta diklat membuat kelompok belajar. Dalam pelaksanaannya widyaswara/tenaga pengajar selalu menyuruh peserta diklat untuk membentuk kelompok belajar, dibentuknya kelompok belajar ini biasanya ada pekerjaan yang membutuhkan kekompakan dari masing-masing anggota, (f) peserta diklat praktek membuat RPP. Dalam pelaksanaannya setiap peserta diklat dilatih untuk menyusun RPP, praktek ini untuk mengetahui sejauh mana setiap peserta sudah mahir atau belum dalam menyusun RPP. Dengan demikian dapat direkomendasikan bahwa aspek proses program diklat teknis substantif penyusunan RPP di Balai Diklat Keagamaan Medan tahun 2020 dapat diteruskan.

4. Produk program peningkatan kompetensi guru madrasah pada diklat teknis substantif penyusunan RPP di Balai Diklat Keagamaan Medan, dapat disimpulkan bahwa: (a) Guru kurang memahami kompetensi inti dan kompetensi dasar pada RPP, guru hanya mengetahui sebatas bahwa Kompetensi Inti dan Kompetensi Dasar adalah ketetapan dari pemerintah dan guru harus menyesuaikan komponen lainnya dengan ketetapan tersebut, (b) Guru dapat merumuskan indikator, hal ini terlihat dari dokumen RPP yang telah dibuat oleh guru, bahwa indikator yang disusun mengacu pada kompetensi dasar dan materi pembelajaran kemudian disusun menggunakan kata kerja operasional, (c) Guru mampu merumuskan tujuan pembelajaran. Dalam merumuskan tujuan pembelajaran guru-guru terlebih dahulu melihat rumusan $\mathrm{KI}$ dan $\mathrm{KD}$, (d) Guru dapat menentukan metode pembelajaran. Bahwa dalam menentukan metode pembelajaran terlebih dahulu guru-guru menyesuaikan dengan materi yang akan diajarkan, metode yang digunakan beragam seperti metode ceramah, metode demonstrasi, metode penugasan, metode kelompok dan metode praktek, (e) Guru dapat menyusun kegiatan pembelajaran. Dalam menyusun kegiatan pembelajaran guru membaginya kedalam 3 kegiatan yaitu kegiatan pendahuluan, kegiatan inti dan kegiatan penutup. Pada kegiatan pendahuluan pembelajaran dimulai dengan membacakan doa, menyanyikan lagu wajib dan mendata kehadiran siswa, dan pada kegiatan pendahuluan ini juga akan dibahas tentang materi yang akan dibahas. Kemudian pada kegiatan inti, terjadinya proses pembelajaran. Pada kegiatan inti ini akan dibahas segala materi pembelajaran, bagaimana pembelajaran itu dikemas oleh guru, dan bagaimana guru-guru menggunakan metode pembelajaran. Dan pada kegiatan ini akan terjadi penilaian proses yang dilakukan oleh guru kepada peserta didik. Lalu kemudian yang terakhir adalah kegiatan penutup, pada kegiatan ini guru dan peserta didik membuat kesimpulan dari materi yang sudah dibahas, pada kegiatan penutup ini pula akan dibahas tentang materi yang akan dibahas pada pertemuan selanjutnya, (f) Guru dapat merumuskan sumber dan media pembelajaran. Dalam hal ini guruguru sudah bisa membedakan antara sumber belajar dan media belajar. Dilihat 
dari dokumen RPP terlihat perbedaan yang sangat signifikan antara sumber belajar dan media belajar. Sumber belajar diambil dari buku-buku, narasumber dan lain-lain, sementara media belajar menggunakan leptop, infokus dan lainnya, (g) guru dapat merumuskan penilaian dalam pembelajaran. Dalam hal ini guru sudah bisa menentukan prosedur penilaian dan instrument penilaian. Kemudian masingmasing item tersebut terdiri dari penilaian proses dan penilaian hasil belajar. Dengan demikian dapat direkomendasikan bahwa aspek produk program diklat teknis substantif penyusunan RPP di Balai Diklat Keagamaan Medan tahun 2020 dapat diteruskan dengan perbaikan.

\section{DAFTAR PUSTAKA}

Abidin, Zinal. 2010. Evaluasi Pembelajaran. Jakakarta: Rineka Cipta.

Anderson, Scarvia. 1975. Encyclopedia on Evaluation. California: Josses-Bass, Inc. Publishet.

Darma, I Ketut. 2019. "The Effectiveness of Teaching Program of CIPP Evaluation Model: Department of Mechanical Engineering, Politeknik Negeri Bali" dalam International Research Journal of Engineering, IT \& Scientific Research, vol. 5, No. 3.

Darmayanti, Stovika Eva, el, at. 2014."Evaluasi Program Pendidikan Karakter Di Sekolah Dasar Kabupaten Kulon Progo" dalam jurnal Prima Edukasia, vol. 2, no. 2.

Fahmi, Asma Hasan. 1979. Sejarah dan Filsafat Pendidikan Islam. Jakarta: Bulan Bintang.

Hamalik, Oemar. 1994. Kurikulum dan Pembelajaran. Bandung: Bumi Aksara. 2008. Pendidikan Guru

Berdasarkan Pendekatan Kompetensi. Jakarta: Bumi Aksara.

Kurnia, Feni, et, al. "Developing Instruments using CIPP Evaluation Model in the
Implementation of Portfolio Assessment in Science Learning" dalam International Journal Of Environmental \& Science Education, Vol. 12, No. 8.

Kusmanto, Agung Selamet, et. al. 2014. "The Development Of Evaluation Program Model Guidance And Counseling Service Based On Cse-Ucla Of Juniro High School In Kudus" dalam Journal of Educational Research and Evaluation, vol. 3 (1).

Ningrum, Epon. 2018. "Evaluation of Learning System on Teacher Educational Profession Programs" dalam Jounal Mimbar, vol. 34, no. 2.

Prayitno. 2009. Teori dan Praksis Pendidikan. Padang: UNP Press.

Sanjaya, Wina. 2006. Pembelajaran dalam Implementasi Kurikulum Berbasis Kompetensi. Jakarta: Kencana Prenada Group.

Sukardi. 2015. Evaluasi Pendidikan dan Kepelatihan. Jakarta: Bumi Aksara.

Sukmadinata, Nana Syaodih. 2007. Metodologi Penelitian Pendidikan. Bandung: Remaja Rosda Karya.

Tayib Napis, Farida Yusuf. 2008. Evaluasi Pendidikan dan Instrumen Evaluasi. Jakarta: Rineka Cipta.

Tim Penulis. 2000. Kamus Besar Bahasa Indonesia (KBBI). Departemen Pendidikan Nasional: Balai Pustaka.

Tirtarahardja, Umar, dkk. 2005. Pengantar Pendidikan. Jakarta: Rineka Cipta.

UU No. 20 SISDIKNAS Tahun 2003

UU RI No. 14 Tahun 2005 Tentang Guru dan Dosen

UU No. 43 Tahun 1999 Tentang Pokok-pokok Kepagawaian 
